\title{
Urban outbreak of acute orally acquired Chagas disease in Táchira, Venezuela
}

\author{
Jesús A. Benítez ${ }^{1,2}$, Benjamín Araujo ${ }^{3}$, Krisell Contreras ${ }^{4}$, Marianela Rivas ${ }^{5}$, Pedro Ramírez ${ }^{6}$, Watermo \\ Guerra $^{7}$, Noel Calderon ${ }^{8}$, Carlo Ascaso Terren ${ }^{9}$, Reggie Barrera ${ }^{8}$, Alfonso J. Rodríguez-Morales ${ }^{10,11,12}$ \\ ${ }^{1}$ Chief, Chagas Disease National Program, Ministry of Health, Maracay, Aragua, Venezuela \\ ${ }^{2}$ Program in International Medicine, Universidad de Barcelona, Barcelona, Spain \\ ${ }^{3}$ Pediatrics Service, ${ }^{4}$ Infectious Diseases Service, ${ }^{5}$ Pediatric Cardiology Service, Centro Clínico San Cristóbal, San \\ Cristóbal, Táchira, Venezuela \\ ${ }^{6}$ Hematology Service, ${ }^{7}$ Pathology Service, Hospital Central de San Cristóbal, San Cristóbal, Táchira, Venezuela \\ ${ }^{8}$ Regional Epidemiology, Corposalud, San Cristóbal, Táchira, Venezuela. \\ ${ }^{9}$ Departament of Public Health, Unit of Biostatistics; Faculty of Medicine, Universidad de Barcelona, Barcelona, \\ Spain \\ ${ }^{10}$ Instituto José Witremundo Torrealba, Universidad de Los Andes, Trujillo, Trujillo, Venezuela \\ ${ }^{11}$ Faculty of Health Sciences, Universidad Tecnológica de Pereira, Pereira, Risaralda, Colombia \\ ${ }^{12}$ Office of Scientific Research, Cooperativa de Entidades de Salud de Risaralda (COODESURIS), Pereira, \\ Risaralda, Colombia
}

Key words: chagas disease; outbreak; acute; oral; transmission; Venezuela

J Infect Dev Ctries 2013; 7(8):638-641. doi:10.3855/jidc.3620

(Received 02 April 2013 - Accepted 15 July 2013)

Copyright $(2013$ Benítez et al. This is an open-access article distributed under the Creative Commons Attribution License, which permits unrestricted use, distribution, and reproduction in any medium, provided the original work is properly cited.

Acute orally acquired Chagas disease (AOACD) has emerged as a significant threat in some countries of South America [1,2]. Until March 2013, at least four have reported outbreaks of acute orally acquired Chagas disease, specifically Brazil [3], Venezuela [4], Colombia [5] and Bolivia [6]. Outbreaks are also likely occurring in Argentina and Ecuador, according to some old reports [2]. In Venezuela, there have been at least three well-known epidemiological reports of AOACD, the first in 2007 at Caracas (Chacao) [4], the second in 2009 at Vargas [7] and the third in 2010 at Caracas (Antimano) [8]. A common feature of these outbreaks is that they have affected predominantly children and have led to a high fatality rate among confirmed cases. Reports describing the investigation of these outbreaks are of high scientific and epidemiological significance; however, information on only the first outbreak has been published [4]. For these reasons we report the findings of the fourth outbreak of AOACD that occurred in Venezuela, in Táchira state (Figure).

On October 2010, a two-year-old girl from Rubio, Junín municipality, Táchira state in western Venezuela (border municipality and state, with Norte de Santander, Colombia) (Figure), was admitted with the diagnosis of an atypical pneumonia at the Centro Clínico San Cristóbal, a private medical center in San Cristobal, the capital city of the Táchira state. After being hospitalized, the patient developed fever, pericarditis, pericardial and pleural effusions, lower lip edema, ascites and hepatosplenomegaly (lasting 16 days). Sixteen days post-admission, a blood smear was performed by a hematologist, who found a motile trypomastigote on the slide. The next day, the patient's status worsened and she died. Necropsy performed at the pathology service of the Hospital Central de San Cristóbal found amastigotes of Trypanosoma cruzi at the myocardium sections.

Based on this case, which occurred in an urban area, in a patient without history of living in an infested rural area and no apparent exposure to triatomine vectors at her house, an investigation of her house and her relatives was made. Six people were living in the house, including the index case; the other five persons living in the house were found positive for Chagas disease by at least two of the following tests: enzyme- 
Figure. Study area of the AOACD outbreak, Táchira, Venezuela, November 2010

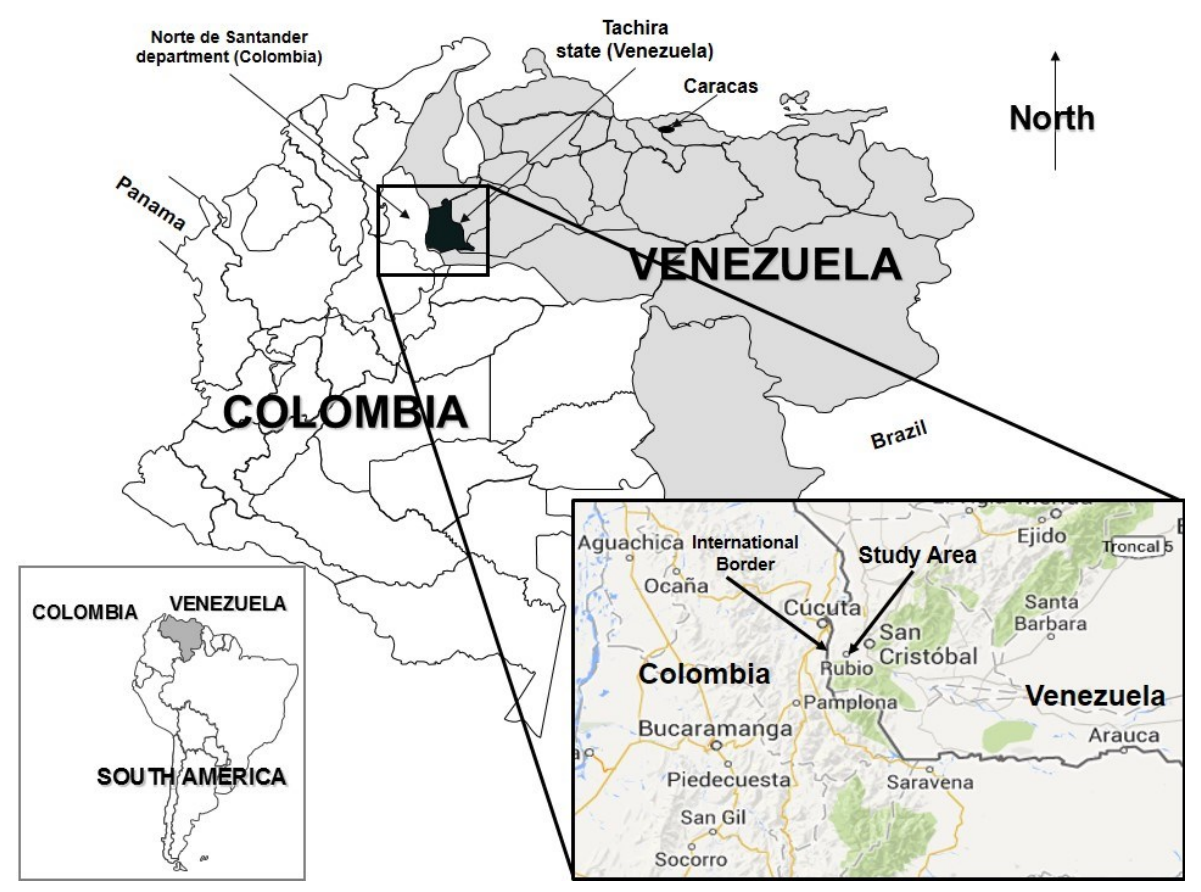

linked immunosorbent assay (ELISA) for IgG anti- $T$. cruzi, indirect immunofluorescence (IFI) anti-T. cruzi, and indirect haemagglutination (IH) anti-T. cruzi. The direct parasitological test using a blood smear was negative in all five subjects (Table). These patients presented facial edema and lymph node enlargement in the neck and lower limbs, concurrently to the time of the index case's symptoms. These cases were admitted to the Hospital Central de San Cristóbal. All the patients (except the index patient), received benznidazole at a dose of $1.5 \mathrm{mg} / \mathrm{kg} /$ day PO, and all were followed up until the end of the complete course of treatment (90 days). The treatment was successful in all individuals (Table). No triatomines were found in the surrounding area of the house or reported by the people living in the house during the entomological investigation. No blood transfusion or transplant history was reported in any of the cases. A foodborne source was not identified, but was suspected as the mode of transmission.

Additional to the house investigation, the school attended by the index case was visited, where 26 blood samples for smears and serological tests were taken, and all of them tested negative. At this school, no additional cases were found, but one specimen of Panstrongylus geniculatus was found, captured and identified. All the neighbourhood houses of the children attending the school were also investigated. A total of 51 dwellings were evaluated, out of which 46
$(90.2 \%)$ were sprayed with pyrethroids, while five owners did not allow spraying. From these houses, 63 people were additionally investigated, and no additional cases were found. A total of 178 serological samples were taken and assessed (all were negative). Additionally, 240 peri-domiciliary nebulizations were performed.

As part of the surveillance of new cases, all the hospitals and the health system of the Táchira state were notified about this situation. The regional health authority was supplied with 1,500 tablets of benznidazole $(100 \mathrm{mg})$. Finally, education in the sector where the outbreak occurred was also performed, giving information to the community about the disease features as well as the triatomine insects related to Chagas disease transmission and preventive and control measures. As the transmission of this outbreak was attributed to ingestion, education was also given to the school and community restaurants with the cooperation of the Ministry of Health, the Ministry of Education, and the Ministry of Foods of Venezuela.

Chagas disease is considered a neglected tropical disease. Even in endemic countries, it has been neglected by health authorities and academic groups, which has in part been the case in Venezuela, where some reports have suggested that this disease is being eliminated [9]. However, research groups have reported the occurrence of acute Chagas disease in 
Table. Summary of the cases of the AOACD outbreak, Táchira, Venezuela, November 2010

\begin{tabular}{|c|c|c|c|c|c|c|c|c|c|}
\hline \multirow[b]{2}{*}{ \# } & \multirow[b]{2}{*}{ Age (years) } & \multirow[b]{2}{*}{ Sex } & \multirow[b]{2}{*}{ Time living in the area (years) } & \multirow[b]{2}{*}{ Occupation } & \multicolumn{4}{|c|}{ Test performed } & \multirow[b]{2}{*}{ Outcome } \\
\hline & & & & & BS & ELISA IgG & IFI & IH & \\
\hline 1 & 2 & $\mathrm{~F}$ & 2 & Pre-scholar & + & NT & NT & NT & Died* \\
\hline 2 & 2 & $\mathrm{~F}$ & 2 & Pre-scholar & - & + & + & - & Survived \\
\hline 3 & 26 & $\mathrm{~F}$ & 25 & $\begin{array}{l}\text { University } \\
\text { Student }\end{array}$ & - & + & + & - & Survived \\
\hline 4 & 24 & $\mathrm{~F}$ & 24 & Teacher & - & + & - & + & Survived \\
\hline 5 & 42 & $\mathrm{~F}$ & 30 & Housewife & - & + & + & - & Survived \\
\hline 6 & 31 & M & 31 & Informatics & - & + & - & + & Survived \\
\hline
\end{tabular}

rural areas for more than a decade ago [10], particularly in western Venezuela. The main mode of transmission is still vector-borne. During the year 2011, entomological surveys of the Chagas Disease National Program in 13 out of 24 states in the country found $170(12.44 \%)$ positive triatomines after a total of 1,367 specimens were collected. That positivity rate was higher in state Táchira $(17.65 \%)$, finding Rhodnius prolixus (the main vector in the country), Triatoma maculata, and Pastrongylus geniculatus, among other species. In the same year, the program took 5,451 samples for immunodiagnosis of $T$. cruzi infection in 16 states, finding 201 of them positive by ELISA IgG plus IFI/IH (3.69\%), with $1.85 \%$ positive in in children younger than 10 years old. There were no positive results for state of Táchira [11].

In the light of these recent outbreaks of acute and oral Chagas disease, [1], awareness and knowledge of these epidemiological patterns should be raised continuously in the biomedical literature and by the public health authorities in endemic countries, as well as in those countries with migration-related risk for Chagas disease [1,12]. Chagas syndrome is a neglected disease, but it has clearly not disappeared and can carry a significant case fatality rate $(\sim 17 \%$; $1 / 6)$, as seen in the Táchira outbreak. Furthermore, sustained efforts to increase epidemiological surveillance, to investigate its transmission as a foodborne disease, to increase testing at blood banks [13] and in those patients with clinical suspicious findings [14], as well as to increase operational, basic and clinical research, should be maintained, particularly in highly endemic countries such as Venezuela, Brazil, Colombia, Bolivia, Ecuador and Argentina, among others.
These changes in parasite transmission in Chagas disease, to include oral transmission, highlight the need for new strategies of prevention and control. It is necessary to consider this infection as a zoonotic, vector-borne and food-borne condition. Strategies for prevention and control should include the building of sustainable surveillance systems [15], which can allow the reporting of the presence of potential vectors of this trypanosomiasis. Ideally, this approach would be enhanced by the participation of communities in endemic areas to support the local, regional and national health authorities and control programs in the actions for the vectorial control. As has been previously reported [15], these strategies could decrease and mitigate the risk of transmission.

\section{References}

1. Rodriguez-Morales AJ (2008) Chagas disease: an emerging food-borne entity? J Infect Dev Ctries 2: 149-150.

2. Toso A, Vial F, Galanti N (2011) Transmisión de la enfermedad de Chagas por vía oral. Rev Med Chile 139: 258266.

3. Benchimol Barbosa PR (2006) The oral transmission of Chagas' disease: an acute form of infection responsible for regional outbreaks. Int J Cardiol 112: 132-133.

4. Alarcón de Noya B, Díaz-Bello Z, Colmenares C, RuizGuevara R, Mauriello L, Zavala-Jaspe R, Suarez JA, Abate T, Naranjo L, Paiva M, Rivas L, Castro J, Márques J, Mendoza I, Acquatella H, Torres J, Noya O (2010) Large urban outbreak of orally acquired acute Chagas disease at a school in Caracas, Venezuela. J Infect Dis 201: 1308-1315.

5. Ríos JF, Arboleda M, Montoya AN, Alarcón EP, Parra-Henao GJ (2011) Probable brote de transmisión oral de enfermedad de Chagas en Turbo, Antioquia. Biomédica 31: 185-195.

6. Vargas JS, Carrasco PO, Espinoza E, Rios T, Brutus L (2011) Primer brote reportado de la enfermedad de chagas en la Amazonía Boliviana: reporte de 14 casos agudos por transmisión oral de Trypanosoma cruzi en Guayaramerín, Beni-Bolivia. BIOFARBO 19: 52-58. 
7. ProMED-mail. Trypanosomiasis, foodborne - Venezuela: (Vargas), guava juice. ProMED-mail 2009; 06 Apr: 20090406.1328. <http://www.promedmail.org>. Accessed 20 March 2013.

8. ProMED-mail. Trypanosomiasis, foodborne - Venezuela: Caracas. ProMED-mail 2010; 09 May: 20100509.1517. $<$ http://www.promedmail.org $>$. Accessed 20 March 2013.

9. Aché A, Matos AJ (2001) Interrupting Chagas disease transmission in Venezuela. Rev Inst Med Trop Sao Paulo 43: $37-43$.

10. Añez N, Carrasco H, Parada H, Crisante G, Rojas A, Gonzalez N, Ramirez JL, Guevara P, Rivero C, Borges R, Scorza JV (1999) Acute Chagas' disease in western Venezuela: a clinical, seroparasitologic, and epidemiologic study. Am J Trop Med Hyg 60: 215-222.

11. Ministry of Health (2013) Epidemiological and entomological report of the Chagas Disease National Program.

12. Carter YL, Juliano JJ, Montgomery SP, Qvarnstrom Y (2012) Acute Chagas disease in a returning traveler. Am J Trop Med Hyg 87: 1038-1040.

13. Herrera-Martínez AD, Rodriguez-Morales AJ (2010) Trends in the seroprevalence of antibodies against Trypanosoma cruzi among blood donors in a Western Hospital of Venezuela, 2004-2008. Acta Trop 116: 115-117.

14. Hidron A, Vogenthaler N, Santos-Preciado JI, RodriguezMorales AJ, Franco-Paredes C, Rassi A Jr (2010) Cardiac involvement with parasitic infections. Clin Microbiol Rev 23: 324-349.

15. Benítez JA, Rodríguez-Morales AJ, Salas MC, Maldonado C, Reyes P (2007) Puestos de Notificación de Triatominos (PNTs) como Alternativa de Vigilancia Epidemiológica No Convencional para la Enfermedad de Chagas en Venezuela. Acta Cient Estud 5: 147-163.

\section{Corresponding author}

Jesús A. Benítez

Chief, Chagas Disease National Program

Ministry of Health

Maracay, Aragua, Venezuela

Telephone/Fax:

Email: drjesusbenitez@yahoo.es

Conflict of interests: No conflict of interests is declared. 